\title{
Governors, Regents, and Rituals: an Exploration of Colonial Diplomacy in Ambon at the Turn of the Nineteenth Century
}

\author{
Philip Post \\ Leiden University, Leiden, the Netherlands \\ philippost@gmail.com
}

\begin{abstract}
This article analyses how the Dutch colonial state in Ambon in the early nineteenth century tried to reestablish relations with local regents, making use of already existing protocols that were produced during the period of the Vereenigde Oostindische Compagnie (1602-1799). Engaging in colonial diplomacy was very important because the demise of the voc (1796) and two short periods of British rule in Ambon (1796-1803 and 1810-17) had shaken Dutch rule to its foundations. To reestablish its legitimacy with these local rulers, the colonial state made use of diplomatic protocols, documents and rituals which had been drawn up and negotiated by the voc. This article will focus on comparing the so-called "Instruction for the Regents," which was drawn up in 1771 by a vOC administrator, with one that was reissued in 1818 by the colonial state and will analyze a number of rituals and protocols which played an important role in defining the relationship between the governor and the regents.
\end{abstract}

\section{Keywords}

colonial diplomacy - Moluccas - Dutch East India Company - Dutch East Indies

\section{Introduction and Historiography}

When the botanist Caspar Reinwardt visited the Moluccan Islands in 1821, he not only made observations about the incredible biodiversity of these islands, but also noted his surprise about an object that some of the local regents 
carried as a sign of their distinction and their adherence to the Dutch colonial state. His surprise was triggered by the observation the regents all carried sticks with golden and silver knobs with a sign not of the Dutch monarch or a different symbol of the Dutch state, as he expected, but of the Dutch East India Company, the trading company which had ruled over the Moluccas from the middle of the seventeenth century onwards, but which had gone bankrupt at the end of the eighteenth century. ${ }^{1}$ The Moluccan Islands were, after all, now part of the Dutch East Indies, i.e. the Dutch colonial state which was formally established in 1816 . So why would these symbols of the already expired trading company, which had been heavily criticized in the course of the eighteenth century for its oppressive and monopolistic trading policies, still be used by these regents who were now part of the Dutch state? Reinwardt left it at that and continued with observations about the natural life of the Moluccas, which he wrote down and finally published in Amsterdam in 1858. This article will expand on Reinwardt's observations and will demonstrate that the continued use of these sticks with the sign of the Dutch East India Company was not an isolated phenomenon, but that it points to a broader role which the Company's legacies would have in shaping the relations between the Dutch colonial government and the Ambonese regents.

This article analyses how colonial officials in Ambon in the early nineteenth century made use of regulations and rituals that had been created in the period of the Dutch East India Company (Vereenigde Oostindische Compagnie or voc) in giving shape to their relations with local, Ambonese regents. When the voc, traditionally seen as a trading company active in Asia between 1602 and 1799, went bankrupt at the end of the eighteenth century, its possessions, including Ambon, were taken over by the British. After two British interregna (in 1796-1803 and 1810-17), Dutch authority in Ambon had to be re-established, but now rule was not exercised by a trading company, but by a colonial state. This article argues that the legacies of the voc played an important role in shaping the diplomatic practices of the colonial state. It will zoom in on multiple writings of the Governor of Ambon, the highest regional official, and show that in many instances use was made of documents and knowledge produced in the eighteenth century to give shape to the position of local regents in Ambon. It will focus on how the colonial government in 1818 reissued a document concerning "instructions for the local regents," which was first drawn up by a voc governor in 1771. Furthermore, it will show that many of the rituals, such as the carrying of sticks, which played an important role in 1821 (Amsterdam: F. Muller, 1858), 439. 
the interactions between the colonial state and the Ambonese regents, were based on ones that had been negotiated in the eighteenth century.

In the last two decades multiple scholars have investigated the ways trading companies, such as voc and its British counterpart, the East India Company, carved out a role for themselves in well-established diplomatic communities throughout Asia. ${ }^{2}$ That this interest into such diplomatic practices has only come about recently, can be explained by the fact that for a long time many historians were primarily interested in analyzing these companies as trading powers and were less focused on investigating their state-like features. Concerning the voc, there has been a tremendous amount of research on figuring out the types of commodities it traded in, ${ }^{3}$ the way it carved out a role for itself in the Asian trading networks in the seventeenth and eighteenth centuries, and there have been analyses of how the voc introduced all kinds of novel financial instruments, ${ }^{4}$ which allowed it to raise enormous funds to increase the volume of trade between Asia and Europe. ${ }^{5}$ Scholars have increasingly emphasized, however, that in the early modern period trade, politics and war were inextricably linked. Gerrit Knaap, for example, has shown that in order to protect its monopolies, the voc needed an extensive military apparatus, which, during the two centuries of its existence, was almost constantly involved in waging war against local rulers. In order to understand how trading companies traded, it is therefore necessary to understand the political context in which they operated. Knaap states that attempts to "depict the success of the voc as solely the result of Dutch commercial entrepreneurship is a mystification, which suits the image that the Netherlands attempts to create for itself in this post-colonial world." ${ }^{6}$

The scholars who emphasized the state-like features naturally also analyzed the way the voc interacted with Asian rulers and traders. They have stressed that the ability to create trading posts and maintain these was only possible by engaging in diplomacy.7 Bhawan Ruangsilp has emphasized that "commercial

2 See, for example, Van Meersbergen, G. "The Diplomatic Repertoires of the East India Companies in Mughal South Asia." Historical Journal 62 (4) (2019), and Blussé, L. Tussen geveinsde vrunden en verklaarde vijanden (Amsterdam: KNAW, 1999).

3 Jacobs, E.M. Koopman in Azië. De handel van de Verenigde Oost-Indische Compagnie tijdens de 18e eeuw (Zutphen: Walburg Pers, 200o).

4 Gaastra, F.S. Bewind en beleid bij de VOC. De financiële en commerciële politiek van de bewindhebbers (Zutphen: Walburg Pers, 1989).

5 Glamann, K. Dutch-Asiatic Trade, 1620-1740 (The Hague: Martinus Nijhoff, 1958).

6 Knaap, G. De 'Core Business' van de VOC. Markt, macht en mentaliteit vanuit overzees perspectief, Inaugural Lecture, Utrecht, 214, accessed via https://dspace.library.uu.nl/ bitstream/handle/1874/308351/Knaap_Gerrit_oratie.pdf.

7 Clulow, A., and T. Mostert, eds. The Dutch and English East India Companies: Diplomacy, Trade and Violence in Early Modern Asia (Amsterdam: AUP, 2018). 
gain and territorial expansion were inseparable parts of the Company's dealings in its interaction with both its European competitors and its Asian counterparts." 8 This research into the way the voc conducted diplomacy has been highly influenced by insights from New Diplomatic History, which has emphasized the importance of non-state actors (such as trading companies) and the role of cultural and material aspects of diplomatic encounters. ${ }^{9}$ Guido van Meersbergen has explained that "in the process, our notion of early modern diplomacy has been markedly expanded. No longer viewing diplomacy as the exclusive preserve of high politics bounded by a Eurocentric chronology, scholars have also begun to take account of the many contributions of non-European actors to the wider development of diplomatic institutions and practices."10 Important work has been done, for example, on the practice of exchanging gifts, on the rituals surrounding diplomatic missions, and on how in such diplomatic encounters representations about "the other" were (re) negotiated. ${ }^{11}$ Because of this body of work, we now know much more about the way trading companies engaged in diplomacy to carve out a role for themselves in existing Asian trading networks. Less is known, however, about how diplomatic interactions remained crucial once the voc had established itself as a dominant actor within these networks. This is reflected in the fact that the "bulk of studies [on voc and diplomacy] ... have focused on bilateral relations between the Company and a single Asian power," all with a "consistent interest in the Company's early struggles."12 Furthermore, little is known about the legacies of the diplomatic culture that the voc negotiated with Asian rulers. What happened to these diplomatic cultures after the disintegration of the voc? We thus have little insight into how interactions between the colonial state, established in the early nineteenth century, and local rulers in the Indonesian archipelago were shaped by such already existing diplomatic cultures.

This lack of interest in the continuities between the eighteenth and nineteenth centuries is part of a broader phenomenon in research about Dutch imperial history, which is that the periods of the voc and the colonial state are rarely studied in unity. There are, of course, many specialists on the voc and

8 Ruangsilp, B. Dutch East India Merchants at the Court of Ayutthaya: Dutch Perceptions of the Thai Kingdom, c. 1604-1765 (Leiden: Brill, 2007), 7.

9 Sowerby, T.A. "Early Modern Diplomatic History." History Compass 14 (9) (2016), 441-56.

10 Van Meersbergen, G. "Diplomacy in a Provincial Setting the East India Companies in Seventeenth-Century Bengal and Orissa." In The Dutch and English East India Companies, eds. A. Clulow and T. Mostert, 58 .

$11 \quad$ Ibid.

12 Clulow, A., and T. Mostert. "The Dutch East India Company and Business Diplomacy." Diplomatica 2 (1) (2020), 30-31. 
many specialists on the colonial state, but there has been little research on the continuities between them. There is a long historiography which argues that a modern Dutch colonial bureaucracy only emerged in the nineteenth century, without addressing how it might be related to the governance of the voc. Wim van den Doel, for example, starts his exploration of the Dutch colonial bureaucracy in 1808 and quickly scans over how the voc might have shaped the later colonial state. ${ }^{13}$ The same applies to J.H.M. Kommers' monograph on the development of the bureaucracy of the Dutch East Indies, which focuses on the period 1800-1830, without paying much attention to the different ways in which the colonial state took over practices, ideas, networks, traditions and structures from the voc. ${ }^{14}$ Because of this, another historian, Jurrien van Goor, has argued that for a long time "questions on the continuity between the voc and the Dutch East Indian state have scarcely been tackled. The nineteenth century image of a new and modern start after the dark days of the Company is often accepted without further questioning."15 A likely reason for the lack of attention into these continuities is that colonial officials in the nineteenth century emphasized how very different they were compared to the administrators of the voc. Nineteenth-century officials often painted a picture of a historical rupture occurring at the end of the eighteenth century, making it seem unlikely that there were important continuities between the voc and the colonial state.

More recently, several historians have become more critical of this divide between the early modern and the modern period and have instead stressed the important continuities between them. Alicia Schrikker has studied these matters for Ceylon at the turn of the nineteenth century, when Dutch rule was replaced by British rule in 1796 . She has emphasized how resistance against British attempts to introduce new colonial reforms forced them to reintroduce some of the old voc policies. ${ }^{16}$ This shows how important the Dutch colonial legacy was in shaping British rule in Ceylon. Similarly, Eddy Kent has studied colonial governance in British India and has challenged the belief that the transfer from Company to Crown in the course of the nineteenth century should be

\footnotetext{
13 Van den Doel, H.W. De stille macht. Het Europese binnenlands bestuur op Java en Madoera, 1808-1942 (Amsterdam: Bert Bakker, 1994). Kommers, J.H.M. Besturen in een onbekende wereld. Het Europese binnenlands bestuur in Nederlands-Indië 1800-1830 (Meppel: Krips Repo, 1979).

15 Van Goor, J. Prelude to Colonialism, the Dutch in Asia (Hilversum: Uitgeverij Verloren, 2004), 120.

16 Schrikker, A.F. Dutch and British Colonial Intervention in Sri Lanka, 1780-1815: Expansion and Reform (Leiden: Brill, 2007).
} 
seen as constituting a paradigm shift. ${ }^{17} \mathrm{He}$ argues that this transition might have had a lot of symbolic value, but that in the day-to-day administration, civil servants did not have to cope with many changes: they "remained in their offices, with the same roles and responsibilities but with new titles."18 For the nineteenth-century Dutch-Indies, Remco Raben and Ulbe Bosma have already explained that from the perspective of the local Ambonese, "the changes in government in the early nineteenth century, from Dutch to British and back to Dutch, had produced a mere ripple in the deep rhythm of centuries." ${ }^{19}$ In fact, Jurrien van Goor has pointed out that throughout the nineteenth century the colonial state was referred to as the Kompenie, a name which derives from the Dutch East India Company. ${ }^{20}$ This suggests that for local Ambonese the transition from a trading company to a colonial state was not perceived as constituting a fundamental change in policies and governance. The question remains, however, whether this also holds true for the way the colonial government engaged in its diplomatic relations with local Ambonese rulers.

This article argues that it is fruitful to look at the transition from the trading company to the colonial state and that this will enrich our understanding how colonial diplomatic cultures came about. It will do so by analyzing how colonial officials in the early nineteenth century made use of regulations and rituals that were produced by the voc to reestablish its relations with local regents. By having insight into these continuities, it is possible to gain a better understanding of how colonial states, such as the Dutch and the British, were built upon the remnants of the trading companies after these were taken over by them. In addition, it will show that it is worthwhile to analyze how colonial diplomacy was conducted not just as a means to carve out a role in a society, but also as a way to ensure that the relations between different actors within a colonial society could be maintained.

Colonial diplomacy, then, is not about the relations between two sovereign states, but about how, even in colonial societies, where one polity controlled the effective political sovereignty of another, both the colonizers as well as the colonized were constantly engaged in "the classic trilogy of diplomatic activity: information-gathering, communication, and negotiation." ${ }^{21}$ Even though the

17 Kent, E. Corporate Character: Representing Imperial Power in British India, 1786-1901 (Toronto: University of Toronto Press, 2014), 16.

18 Ibid.

19 Bosma, U., and R. Raben. De Oude Indische Wereld: Being "Dutch" in the Indies. A History of Creolisation and Empire, 1500-1920, trans. W. Shaffer (Athens: Ohio University Press, 2008), 143.

$20 \quad$ Van Goor, J. Kooplieden, Predikanten \& Bestuurders Overzee. Beeldvorming en plaatsbepaling in een andere wereld (Utrecht: HES Uitgevers, 1982), 137.

21 Scott-Smith, G., and K. Weisbrode. "Editorial." Diplomatica 1 (1) (2019), 3. 
regents formally played a subordinate role within the Dutch colonial system, the Dutch colonial state in Ambon was very dependent upon them in maintaining the colonial infrastructure. This could only be realized if the regents' autonomous position within Ambonese society was respected. Upholding and supporting the authority that these regents had within Ambonese society was therefore crucial to Dutch colonial designs. The Dutch Governors and the Ambonese regents represented different political communities and diplomacy played a crucial part in shaping these relations. While diplomacy and colonialism might at first glance seem to make strange bedfellows, recent studies have emphasized that "that studying diplomatic culture can elucidate interand intra-imperial dynamics," as can be seen in recent work on the importance of diplomacy in the intra-imperial politics within the Ottoman Empire. ${ }^{22}$ This article aims to show that in the colonial encounters in Asia the ability to engage in diplomacy was of crucial importance as well, both to the colonizers as well as the colonized.

The analysis is structured as follows: it will continue by giving some essential context on how Dutch rule worked in Ambon and will explain what the position of the local regents was in the Dutch colonial administration. It will then discuss why the colonial state reissued the instructions for the regents at the beginning of the nineteenth century. It will compare the ones from 1818 to the ones from 1771 and will study how the colonial state used these instructions to control the regents as a group. It will then address how the Ambonese regents at times managed to use these instructions to their own advantage. Furthermore, it will explain that this relationship was not only determined by formal instructions, but that it was also shaped by all kinds of rituals, such as the exchange of gifts, which were also taken over from the voc.

\section{Change and Continuity in the Moluccas}

The Moluccas are a group of islands, which, from the late sixteenth century onwards, attracted European explorers, most important among them the Portuguese, Spanish, and Dutch. The islands were very important in the seventeenth and eighteenth centuries because they were the only places where

22 Sowerby, T., and J. Hennings, eds. Practices of Diplomacy in the Early Modern World c.14101800 (London: Routledge, 2017), 3. See also the chapter (44-64) by Gábor Kármán in this edited volume for a relevant study on applying diplomacy to the Ottoman Empire. 
spices such as nutmeg, cloves, and mace could be cultivated. ${ }^{23}$ The Dutch quickly beat their competitors and managed to establish a strong foothold on the islands, very often forcing their way through violence and terror. In order to maximize its profits, the voc established a trading monopoly on these profitable spices, which was in place from the middle of the seventeenth century onwards. ${ }^{24}$ This system enabled the voc to buy the spices a fixed price and then sell these with huge profits in Asia itself but also in the rest of the world. The voc needed a strong military and civil presence to protect its monopoly, and, equally important, maintain durable relations with local rulers to administrate a population of around 80,00o inhabitants on the Ambonese islands.

The local regents played an essential part in the way the voc governed, because intervening directly into daily Ambonese affairs was considered to be a very costly affair. The local regents played an important role in mobilizing sufficient labor for the cultivation of cloves and in maintaining the Dutch spice monopoly. Cultivation of spices was only allowed on a number of Ambonese islands: Ambon, Haruku, Saparua, and Nusa Laut. Cultivating cloves on other islands was strictly forbidden and to ensure that people complied with the voc's policy, it instigated inspections tours, which were called hongi expeditions: during a couple of weeks every year, hundreds of voc employees and local Ambonese would visit and inspect dozens of islands to make sure that any cloves grown outside of the islands mentioned above were extirpated. At times, trees were also cut when the prices of cloves had diminished because of overproduction. The regents were also responsible for mobilizing a sufficient amount of people for corvée labor. These laborers played a key role in the maintenance of voc buildings, in delivering letters to and from local regents, in the loading and unloading of ships, and were essential for other tasks that were crucial to the colonial infrastructure. These regents were able to mobilize large amounts of laborers because they held a privileged status within their communities. Most of the time, the main positions within villages were held by a relatively small number of families. Although the Dutch colonial authorities would refer to the village heads as regents, they were known in their own societies as "raja," "patih," or "orangkaya," and, in Dutch historiography, the term regent is mostly used for Javanese rulers. ${ }^{25}$ When a regent would cease his functions, the village elders (the orangkaya) would deliberate amongst

23 Andaya, L. The World of Maluku (Honolulu: University of Hawaii Press, 1993), 1.

24 Knaap G.J. Kruidnagelen en christenen. De Verenigde Oost-Indische Compagnie en de bevolking van Ambon 1656-1696, 2nd ed. (Leiden: KITLV Uitgeverij, 2004).

25 Van Fraassen, C.F. Ambon in het 19-eeuwse Indië, van wingewest tot werfdepot (Amsterdam: De Bataafsche Leeuw, 2018), 73. 
themselves and would then nominate one of them to the colonial government. Most of the time, the colonial government would take over such recommendations from the village elders, after which the nominee would be officially appointed by the Dutch colonial government in Ambon. ${ }^{26}$ Sometimes a regent would pass on his duties to his son, but, just as often, his brother or his brother's son would be appointed. ${ }^{27}$

Contact with the local regents was maintained by the highest regional official: the Governor, and later the Resident, of Ambon. In many ways one could say that for the local Ambonese it was the Governor who embodied Dutch power within the Moluccas. In the eighteenth and nineteenth century, when sending mail still took months, these now-forgotten colonial officials were the men on the spot, often operating like autocrats, combining legislative, executive and judicial powers. Eduard Douwes Dekker put it like this in his Max Havelaar (1860): "It's these residents who actually represent the authority of the Dutch .... The people do not know the Governor-General, nor the councils of the Indies, nor the Directors in Batavia. They know only the Resident."28 These Governors and Residents were responsible for collecting taxes, organizing public order and establishing political relations in their regions. Coercion, mediation and diplomacy formed the key means to achieve this. As the highest regional official the Governor would also spend many hours every day on informing his superiors in Batavia (now Jakarta), the center of the Dutch East India Company and the place of residence of the Governor-General. The Governors and residents mostly hailed from the Dutch Republic and almost all adhered to Calvinism, but the majority had worked in a variety of administrative and political positions in Asia before acceding to the rank of Governor. ${ }^{29}$

While Dutch rule in Ambon had not been fundamentally challenged throughout the eighteenth century, it received two huge blows at the turn of the nineteenth century when the British managed to oust the Dutch twice: first during $1796-1803$ and again during $1810-17$. This was in the context of the revolutionary and Napoleonic wars, when "after the French occupation of the Dutch Republic in 1794-95, Britain considered it vital to secure the former Dutch possessions in the East, both to safeguard the route to India ... and to disrupt the French connection to Asia." ${ }^{30}$ The Treaty of Amiens, signed in 1802, established

\footnotetext{
$26 \quad$ Knaap, G. Kruidnagelen en christenen, 44.

27 Ibid.

28 Dekker, E.D. Max Havelaar Op De Koffieveilingen Van De Nederlandse Handelmaatschappij, 2oth ed. (Amsterdam: L.J. Veen, 2008), 74.

29 Boxer, C.R. The Dutch Seaborne Empire, 16oo-18oo (London: Penguin, 1988), 241-72.

30 Mikaberidze, A. The Napoleonic Wars. A Global History (Oxford: Oxford University Press, 2020), 62 .
} 
peace between Britain and France, after which the Moluccas were returned to the Batavian Republic in the course of $1803 .{ }^{31}$ However, when Dutch authority was restored it was no longer the voc which exercised power, but the Dutch government, which had taken over the voc's possessions when it went bankrupt. A few years after, in 1810, the British again decided to establish themselves in the Moluccan islands as part of a bigger plan to "confirm British dominance of the seas of Cape of the Good Hope," ushering in the second British Interregnum in the Spice Islands, but this time round also establishing their dominance on Java. ${ }^{32}$ The British had already managed to remove the French out of Mauritius a few months earlier, and with the taking over of the Moluccas and Java they had managed to neutralize the French in the Indian Ocean. ${ }^{33}$ With the disintegration of Napoleon's power and the restoration of Dutch monarchy in the hands of William I of Orange, negotiations commenced about returning Dutch colonial possessions. When the British and Dutch government signed the Treaty of London in 1814, they agreed that the Moluccas would be returned to the Dutch, which would eventually take place in 1817 .

It soon turned out that Dutch prestige suffered tremendously after they had been beaten rather easily by the British a few years prior. Rumors about a restoration of Dutch rule led to great discontent among Ambonese rulers, which helped spark off a huge uprising, led by Thomas Matulessy (also known as Pattimura). British rule had been perceived as much softer and was borne more easily by the Ambonese. One local inhabitant had stated that "if the Dutch want to rule us, then they have to be fair and just, like the English were, who kept their promises." ${ }^{34}$ Many Ambonese were angered when they realized that the Dutch officials, who were sent out to take over from the British, did not focus on the interests of the Ambonese, but instead only seemed to care about the profitability of Ambon. Pattimura and scores of local regents, therefore, decided to join forces and tried to make sure that the Dutch were ousted before they could consolidate their power. Between May and November 1817, there were multiple violent clashes between Dutch armed forces and these Ambonese leaders. Months of heavy fighting had caused tremendous bloodshed, but when additional forces arrived from Batavia as well as Ternate and Tidore, the Dutch managed to overwhelm the Ambonese and finally captured

$31 \quad$ Koch, J. Koning Willem I, 1772-1843 (Amsterdam: Boom Uitgeverij, 2013), 125.

$3^{2}$ Mikaberidze, A. The Napoleonic Wars, 498.

33 Sivasundaram, S. Waves Across the South. A New History of Revolution and Empire (London: William Collins, 2020), 230.

34 Quoted in Hagen, P. Koloniale Oorlogen in Indonesië. Vijf Eeuwen Verzet Tegen Vreemde Overheersing (Amsterdam: De Arbeiderspers), 278. 
Pattimura on 13 November. He and dozens of other Ambonese leaders were sentenced to death, causing Ambonese society to lose many of its local leaders.

\section{A Wind of Change?}

After these extremely violent clashes and the defeat of these Ambonese leaders, the Dutch colonial government set about consolidating its powers and expanding its grip on Ambonese society. However, now colonial authority was not exercised by a trading company but by the government of the Dutch East Indies, officially established in 1816 . Scores of Dutch administrators were sent to the Indies, who had not been employed by the voc, and who now had to introduce a new colonial philosophy: it was proclaimed loudly that the race for profits would no longer reign supreme and instead a genuine care for its colonial subjects would be demonstrated. Governor H.M. de Kock, who ruled in Ambon between 1818 and 1819, stated that in his view the Pattimura revolt was based on the perception that the Dutch would base their rule on the "old systems" of the Dutch East India Company. ${ }^{35}$ However, he had tried to reassure the Ambonese colonial subjects that this was not the case. De Kock wrote that "I have made it my pleasant duty to instil respect among the natives (inlander) for the Dutch administration. On all occasions I have received and spoken to the regents and those of the lowest descent, and convey to them that the government, in the broadest terms, desires that the natives (inlander) are ruled softly and justly, and that they are not repressed or treated unfairly"36 De Kock is not alone in discussing these ideas, but part of a whole generation of officials who believed that the Dutch colonial administration would have to be professionalized and rationalized in order to work efficiently and fair. Governor-generals such as Herman Willem Daendels (r.1808-11) and Godert van der Capellen (r.1816-26) believed that the Dutch colonial government should be centralized and professionalized by establishing new institutions, such as a General Secretariat and a Court of Audit, but also by improving communications between the different Residencies and by launching proposals for establishing administrative schools, where new generations of officials could be trained. ${ }^{37}$

Memorie van overgave van afgaand gouverneur der Molukken (generaal-majoor De Kock) aan zijn opvolger (Tielenius Kruijthoff), Ambon, 7 January 1819, accessed 4 September 2020 via http://resources.huygens.knaw.nl/retroboeken/ middenmolukken17961902/?page_number=1819-01-07. Ibid.

37 Van den Doel, H.W. De Stille Macht, 37-53. 


\section{Old and New Instructions}

While such plans were being discussed in Batavia, De Kock realized that in order to collect and ship spices, he was very much dependent on establishing close relations with the Ambonese regents. It is within this context that he issued new formal instructions for the regents in 1818. In the text accompanying the new instructions, he explained that these were necessary because many new regents had been appointed in the last year to replace regents who had joined the widespread resistance against Dutch authority in the Pattimura campaigns and who had been executed or banned to Java as a result of their participation. Many of these new regents were "completely unfamiliar with the old instruction" and De Kock believed the time had come to inform them of their duties and obligations towards the Dutch colonial state. ${ }^{38}$ In addition, the original instructions from 1771 had been updated a number of times and by reissuing the instructions, it would become very clear to all parties involved what their mutual responsibilities were. Furthermore, instructions were not only issued for the local regents, but also for a whole range of Dutch administrators. This could indicate that in the early nineteenth century there was an increased need to formalize what was required of these different administrators. The newly drawn-up instructions for the European administrators were not based on previous ones, but the ones for the local regents were.

The instructions for the regents were first issued on 11 January 1771 by Governor Johan Abraham van der Voort, who had been the highest regional official in Ambon between 1770 and 1775. These instructions were not prefaced by an explanation as to why the colonial authorities deemed it necessary to write up a list with obligations for the local regents, but in another document, written for his successor, Van der Voort seemed to suggest that this was done because the colonial government had been confronted in the late 176 os with some opinionated, Ambonese regents who were considered to have become too independent of the voc. ${ }^{39}$ This was especially problematic because at the end of the 176 os the colonial authorities in the Dutch Republic and in Batavia had ordered that the production of cloves needed to be scaled down as continued overproduction threatened to lead to diminished profits on spices. Reducing the amounts of cloves could only be achieved in the short term by organizing hongi expeditions, during which many clove-trees could be cut

\footnotetext{
38 Idema, H.A. "De oorzaken van den opstand van Saparoea in 1817." Bijdragen tot de taal-, land- en volkenkunde / Journal of the Humanities and Social Sciences of Southeast Asia 79 (1) (1923), 619.

39 National Archives, The Hague, voc Archive (1.04.02); 3329; fifth register; folio 2.
} 
down. To organize these successfully, the local regents had to be very aware of their role and obligations, which could explain why the colonial authorities decided on writing these down in detailed instructions. ${ }^{40}$

\section{Comparison of the Instructions}

The instruction of 1771 contains a total of 50 articles, whereas the revised one reissued in 1818 consists of 45 articles, but in general they are very similar in scope and in content. Some articles are very broad in intent and cover general principles of proper conduct, whereas other instructions are very specific and leave little doubt about their application. It is mainly these latter articles which have been revised and updated in 1818 . The more general articles have been copied almost verbatim.

Both instructions begin the first article with the admonishing words that "all local heads shall rule in a correct and lenient way without engaging in exactions [knevelarijen] and cruelty." ${ }^{11}$ Both instructions then proceed in article 2-4 by discussing the religious obligations incumbent on the regents. The Christian regents need to ensure the proper observance of religious rites by their Christian subjects and have to see to it that Christian children attend school. Both Christian and Islamic regents need to make sure that their subordinates do not engage in religious conflicts, which is also why Christians are not allowed to marry Islamic women and Islamic men may not marry Christian women. The Dutch colonial government was very dependent on local Ambonese to perform all types of labor and the instructions therefore continue with a few articles on discussing the types of corvée-labor that local Ambonese have to perform for the colonial government and for the regents themselves. The regents are instructed only to have their subjects perform the types of labor which they have been authorized by custom to do and not to burden them with additional tasks (art. 5). There then follows a whole list of how many men different regents have to provide to the colonial authorities. These obligations were often based on old contracts. For example, in article 9 of the new instructions and article 10 of the old ones, it is mentioned that "the inhabitants of Manipa are obliged by contract (February seventeenth 1622) to build and repair the redoubts and to procure sufficient lime, bricks, timber

40 Knaap, G.J., R. Chaauvel, and C.F. Fraassen. Van Tjengkeh tot kruidnagel (Amsterdam: Stichting Werkgroep Inheemse Volken, 1987), 21.

Ibid.; Idema, H.A. “De oorzaken van den opstand van Saparoea in 1817," 619. 
and workmen, who will not receive any pay."42 This shows that the colonial government justified its authority by making use of treaties which had been negotiated by the voc. This can be seen as another layer of continuity between the voc and the colonial state.

However, this does not mean that these obligations remained completely the same. In fact, it is mainly with respect to the specific obligations that the two instructions are different. This is easily explained by changing population numbers: regents who were in control over areas whose populations had increased were obliged to provide the colonial government with more men, and regents who ruled over places whose number of inhabitants had decreased had to supply fewer men. The instructions also specify the amounts of materials that the regents would have to supply to the colonial government. Furthermore, both instructions contained precise details on the role of the regents in organizing the hongi expeditions, indicating how many men as well as the amount of boats and materials they would have to provide to the colonial government. As we have seen, these inspections were performed to ensure that trees had only been planted in those areas where the colonial government had allowed it. In case clove trees had been planted illegally, they would be cut down in the hongi expedition.

The instructions continued with pointing out what role the regents had in legal cases and how their succession was to be arranged. One of the main tasks of the regents was to supervise and ensure the proper cultivation of cloves. Instructions concerning this process were discussed in article 26 in the revised instructions and contain information on when and how this was to be done. Furthermore, details were given on how the cloves were to be measured and handed over to officials of the colonial government. Both instructions continued with pointing out that no private trade of cloves was allowed and that those who would do so anyway would be severely punished. The regents were admonished not to meet with foreign traders and are obligated to notify the colonial authorities when foreigners appear at the coast. Furthermore, local Ambonese were not allowed to leave Ambon and could not e.g. visit Batavia. The instructions ended with instructions on dealing with persons who were affected with leprosy.

This overview shows that the contents of both instructions are very similar. Both are structured in the same manner and contain the same principles which the local regents have to adhere to. In addition, both documents are not just focused on the role of the regents in the cultivation of cloves, but also contain articles on the administration of justice, on the observance of 
religious practices, on principles of proper governance and on meeting with foreign traders. Furthermore, while some of the specific obligations may have changed between 1771 and 1818 , the general outlook on the role of the regents remained the same. Furthermore, the broad scope of the instructions show that the voc focused on much more than just trade. Its powers and claims to authority covered many spheres of life, including religion, sexuality, and politics.

\section{The Use of the Instructions}

How exactly did the colonial government use these revised instructions? Naturally, one of the primary aims of this document was that it enabled it to keep tabs on the regents. The instructions were intended and used to concretize and fix the obligations of the regents as a group and thereby make it easier to control them. It gave the colonial government an organized and detailed list of many of the obligations that the regents had to fulfil. Having such a list also led to less flexibility in the interactions between regents and the colonial government. Because the instructions were so detailed, they also helped the European officials in knowing when local rulers did not fulfil their obligations and therefore could be reprimanded. It is interesting to note, however, that the instruction was also used by colonial officials to acquaint themselves with how the colonial bureaucracy worked and learn about the role played by Ambonese regents within this system. In a document that Governor H.M. de Kock wrote in 1819 for his successor, H. Tielenius Kruijthoff, he explained that "to acquaint yourself with local affairs, dare I recommend Your Excellency to read the Instruction of the Regents, which I have already cited. This is an old document, which I have reissued with some changes." ${ }^{\prime 3}$ De Kock refers to the Instruction again when discussing the organization of the hongi expedition, explaining that the document provides insight into what boats are to be employed and which provisions are to be made. ${ }^{4}$

43 Memorie van overgave van afgaand gouverneur der Molukken (generaal-majoor De Kock) aan zijn opvolger (Tielenius Kruijthoff), Ambon, 7 January 1819, accessed 23 February 2020 via http://resources.huygens.knaw.nl/retroboeken/ middenmolukken17961902/?page_number=1819-01-07. 


\section{Negotiating Colonial Rule}

However, this does not mean that the local regents always passively accepted what was written down in the instructions. Sometimes the local regents would not be able to fulfil their obligations and would have to negotiate about alternative ways to satisfy the demands of colonial government. Archival documents from the National Archive in Jakarta contain documents describing meetings in which local regents met with the Governor, or one of his subordinates, and would, in case they could not oblige with the instructions, negotiate with the colonial government about meeting its demands. A meeting that was held on the 22nd of January 1810 between the prefect from Haruku, a subordinate of the Governor of Ambon, and a number of regents, shows that the regents were very aware that the instructions were not set in stone. The regents, whose names were not written down in the minutes, explained that they could not provide three orembai (types of boats) for the hongi expedition, which was required according to the Instruction. Instead, they offered to supply the government in Ambon with a few thousand kilos of chalk. They then negotiated about when this was to be supplied and managed to convince the official that they would so much later than the government originally had asked for. ${ }^{45}$

Other sources show examples of how the regents used the instructions to their own advantage in their dealings with the Governors. In the same meeting with the regents of Haruku, these local rulers complained about a request from the Governor to provide the main castle with 12 men for corvée labor, as they had never been obliged to do so. The resident who wrote the report then writes that according to the Instruction this was indeed the case. A similar situation presented itself in discussions with the regents of Ceram. They had been asked to provide the Government with oil instead of boats and men for a hongi expedition. The regents replied, however, that there was no obligation for them to supply the government with men for a hongi, and that they were unable to provide the government with oil. ${ }^{46}$

These examples show that the regents did not passively follow everything that they were required to do according to the instruction that was reissued by De Kock. Instead, there are clear examples of them negotiating about complying with certain rules and thereby finding room to maneuver, which is an important element of diplomatic activity. Furthermore, these documents

\footnotetext{
45 Verslag van conferentie van onderprefect van Haruku (Mazel) met regenten van zijn ressort, Haruku, 22 January 1810, accessed 3 March 2020 via http://resources.huygens.knaw. $\mathrm{nl} /$ retroboeken/middenmolukken179619o2 $/ \#$ page $=446 \&$ accessor=toc\&view $=$ htmlPane. 
show that at times the regents also rejected requests from the Governor on the basis of there not being an obligation in the instructions to comply with such a request. This shows that attempts by the government to describe the obligations of the regents and thereby force them to comply with colonial rules more readily, also gave regents the chance to reflect on what exactly the colonial government could ask from them, which empowered them to sometimes resist certain demands from the colonial authorities.

\section{The Rituals of Colonial Diplomacy}

The relations between the colonial government and the local regents were not only formally determined by instructions but were also shaped by a whole range of rituals, protocols and marks of honor. Henk Niemeijer explains that "in the Moluccas the voc bestowed a great deal of attention on ritual expressions which were intended to display respect for Moluccan rulers publicly, thereby camouflaging at least some of the Moluccan discomfiture [with colonial rule]." ${ }^{m 7}$ While the instructions contained a whole range of obligations that the local rulers had towards the colonial state, these rituals were important in shaping the actual diplomatic encounters between representatives of the colonial state and local, Ambonese society. Through these rituals "some Moluccan political frustration with colonial rule was compensated. The outcome was a specific, local diplomatic culture in which various elements from the European and Moluccan politico-cultural contexts were discernible. The local diplomatic 'system of contact,' imbued with a feudal relationship, formed the foundation of eighteenth-century colonialism." 48 These colonial diplomatic cultures had started to emerge from the late sixteenth century onwards, when contacts between European traders and Moluccan rulers had first been established. They had continued in maintaining relations between the voc and the local regents up to the end of the eighteenth century, when voc rule was replaced by the British. When the Dutch colonial state took over from the British, it not only used the old instructions to restore relations with the local regents, but also made use of this whole score of rituals and protocols that had come into being in the previous two centuries.

\footnotetext{
47 Niemeijer, H.E. "The Theatrical Peace: Honour, Protocol and Diplomacy in the Balance of Power between the United East India Company and Ternate c.1750," accessed 9January 2020, via https://www.cortsfoundation.org/images/PDF/Niemeijer20o2_TheTheatricalPeace.pdf. 
One of the most important signs of distinction that the voc, and later the colonial state, gave to the local regents was a deed of appointment. This was a document which was signed by the Governor of the Moluccas and given to every newly appointed regent. Even more important were the sticks with either a silver or a golden knob that were given to Ambonese regents. Johannes Olivier, who accompanied Governor-General Godert van der Capellen on his travels through the Moluccas in 1824, writes that the regents are "especially proud of carrying a long, white stick with a silver or a golden button, on which the Dutch weapon, or that of the [Dutch] East-India Company has been wrought, and which constitutes a sign of their dignity and respect." ${ }^{39} \mathrm{~A}$ stick with a silver knob would be granted to regents who would proclaim to remain loyal to the demands of the colonial state. Ambonese regents who proved to be particularly loyal and effective would be given a stick with a golden knob."50 Some of the travel accounts that were written in the early nineteenth century point out that on Ambon some of the local rulers still used signs of honor that had been introduced by the voc. As we have seen in the introduction, one traveler, the botanist Caspar Georg Carl Reinwardt, wrote that heads of the local villages still used the "stick of the [Dutch] East India Company as their sign of honour." ${ }^{51}$ Johannes Olivier explained that such knobs were considered to be of great value and were therefore saved, stating that "many indigenous [inlandsche] Regents and heads in the Moluccas have a whole collection of these knobs, which their forefathers wore in the time of the Company [Compagnie] and which, regarded as the regalia of their families, are saved with the utmost care." 52

These comments are revealing because they show how signs of honor that were introduced by the voc were still used in the nineteenth century. For local rulers such sticks were incredibly important not only as a token of respect from the colonial state, but also in building up a position of authority within local, Ambonese society. ${ }^{53}$ Their claims to political authority not only depended on carving out a position within Ambonese communities, but were also highly influenced by their standing with the colonial government. For the colonial government, the ability to bestow such gifts and signs of honor were not just important in ensuring that the local regents would remain loyal but were also

\footnotetext{
49 Olivier, J. Reizen in Den Molukschen Archipel Naar Makassar, Enz. (Amsterdam: G.J.A. Beijerinck, 1834), 39 .

$50 \quad$ Ibid.

$51 \quad$ Reinwardt, C.G.C. Reis Naar Het Oostelijk Gedeelte Van Den Indischen Archipel, in Het Jaar 1821. (Amsterdam: F. Muller, 1858), 439.

$5^{2}$ Olivier, J. Reizen in Den Molukschen Archipel Naar Makassar, Enz., 241.

53 Van Fraassen, C.F. Ambon in het rge-eeuwse Indië - van wingewest tot werfdepot, 208-9.
} 
essential in fostering competition among them and making sure that they played an effective role in colonial politics. Olivier wrote that "no Field Marshal will attach more value to his baton than an Ambonese Radja or Orangkaya [regent] will to his Company's stick." ${ }^{4}$ Such tokens thus played an important role in ensuring that local Ambonese rulers competed for loyalty vis-à-vis the colonial state.

The colonial government also continued with another practice which had been started in 1770, which consisted of presenting local regents with linen textiles after they or their subordinates had successfully participated in the hongi expeditions. ${ }^{55}$ Scholars of cultural diplomacy have increasingly stressed the importance of such gifts in diplomacy in the early modern world, pointing to the importance of "gift-giving as a mechanism to successfully establish social hierarchies, reciprocities, and long-term obligations in early modern societies." ${ }^{.5}$ Because of the many functions that gifts could have, multiple scholars have emphasized how they "were an indispensable ingredient of global diplomacy and were central to the establishment and development of global connections." ${ }^{57}$ The practice of giving these gifts had been preceded by a different tradition: between 1662 and 1769 it had been customary to organize a so-called orangkaya feast for the local regents in which the European officials also participated. Many local regents had complained, however, that such a feast required them to remain even longer removed from their families and communities. They had therefore requested to replace this feast with the giving of a gift, usually in the form of linen textiles. ${ }^{58}$ This practice had become well-established at the end of the eighteenth century, but seems to have been discontinued by the British, who did not engage in the hongi expeditions. In the early nineteenth century, when Dutch rule had been restored, the Ambonese rulers had asked colonial officials whether they would continue with either of these. After some deliberations, the colonial government finally decided upon the continuation of the tradition of giving linen cloths.

54 Olivier, J. Reizen in Den Molukschen Archipel, 39.

55 Verbaal handelingen en besluiten gouverneur-generaal (Van der Capellen) in Rade 20 February 1821 no. 27, Batavia, accessed 3 February 2020 via http://resources.huygens.knaw. $\mathrm{nl} /$ retroboeken/middenmolukken179619o2/\#page=1299\&accessor=toc\&source=1.

56 Broomhall, S., and J. Van Gent. Gender, Power and Identity in the Early Modern House of Orange-Nassau (London/New York: Routledge, 2016), 7.

57 Biedermann, Z., A. Gerritsen, and G. Riello. Global Gifts. The Material Culture of Diplomacy in Early Modern Eurasia (Cambridge: Cambridge University Press, 2017), 1.

58 Verbaal handelingen en besluiten gouverneur-generaal (Van der Capellen) buiten Rade 23 June 1819 no. 9, Batavia, accessed 3 February 2020 via http://resources.huygens.knaw.nl/ retroboeken/middenmolukken179619o2/?page_number=1819-o6-23. 
According to H.M. de Kock, Governor of Ambon in 1818, these gifts made a "very advantageous impression on the local inhabitants, while it did not necessitate major expenditures on behalf of the colonial government, [so that he] supports the regents' request wholeheartedly."59

These gifts were not just important to show appreciation towards the regents, but one scholar has recently stressed that they were "key agents of social cohesion and transcultural systems of value." ${ }^{60}$ This was particularly true for the linen textiles that were given to the Ambonese regents, because with such textiles different types of clothes could be made. Such dress was not just important for aesthetical reasons, but also because through clothing identities are constructed, which were then "used to signify membership or dissociation." ${ }^{61}$ Multiple travel accounts comment on the fact that Christian and Islamic regents would dress differently, with the Christian rulers preferring to "imitate the Europeans" by wearing colorful dresses and donning a straw hat, opposed to Islamic regents, who generally preferred to wear a headscarf. ${ }^{62}$ This points to the possibilities that clothing, and gifts more generally, had in creating associations, sentiments and representations that had a crucial part in the maintenance of colonial rule.

These examples show that colonial officials in the early nineteenth century used many rituals that had been formed during the previous two centuries in their dealings with local, Ambonese regents. This was not only because these officials themselves believed that it was advantageous to tap into these existing rituals, but also because Ambonese regents themselves requested their continuation. For them these rituals were not only important because they were already familiar and made dealing with the colonial government more predictable, but also because these already existing rituals enhanced their standing within local, Ambonese society.

\section{Conclusion}

This article has argued that colonial officials in Ambon in the early nineteenth century used regulations and rituals that had been created during the period of the voc to re-establish relations with local regents. It has mainly looked

\footnotetext{
$59 \quad$ See note 23 .

6o Ibid.

61 Hulsbosch, M. Pointy Shoes and Pith Helmets: Dress and Identity Construction in Ambon from 1850 to 1942 (Leiden: Brill, 2014), 3.

62 Olivier, J. Elviro's reis naar en door Java en de Molukkos (Amsterdam: H.W. Weytingh, 1835), 205 .
} 
at how in 1818 instructions were issued concerning the role of the regents in the colonial administration, which were based on ones that had already been drawn up in 1771. These new instructions were very similar to these earlier ones, both in terms of structure as well as contents. Furthermore, many of the rituals on which the relations between the colonial government and the local regents were based, had also come about in the previous century. Especially revealing in this regard are the continued use of types of gifts and signs of honor, which played an important role in the dealings of the Voc with the local regents. It is, of course, not surprising that there is continuity in the practices and rituals of the Voc and the colonial state. Officials in the early nineteenth century must have realized that people were already familiar with these practices, which made it sensible to continue using them. However, it is relevant to highlight that while rhetorically colonial government officials went to great lengths to distance themselves from the way the voc had operated, in practice they often relied on knowledge, protocols, and rituals that it had negotiated. But it was not just the colonial state which reached back to this body of knowledge, local regents themselves also requested the continued use of these rituals, since these played a crucial role in legitimizing their own position within local, Ambonese society. Furthermore, the local regents did not passively accept whatever was written down in these instructions, but played a crucial part in negotiating the way they were interpreted and also managed to use the instructions to their own advantage.

These interactions can best be understood as a form of colonial diplomacy. Even though the Dutch colonial government was the sole sovereign power in Ambon, it was very dependent on the Ambonese regents in its quest for spices. Only with their help was it possible to muster sufficient men to actually plant, harvest, and collect the spices which yielded such incredible profits all over the world. To best protect their interests, governors and regents engaged in "the classic trilogy" of diplomatic activity: "information-gathering, communication, and negotiation," ${ }^{\prime 63}$ with the full realization that maintaining stable relations depended on their mutual recognition of each other's authority through a number of rituals and protocols. Studying these interactions is not only important for gaining insight into the diplomatic cultures of the voc, but is also relevant for a deeper understanding of the development of the colonial state and diplomacy in the nineteenth century.

63 Scott-Smith, G., and K. Weisbrode. "Editorial," 3. 